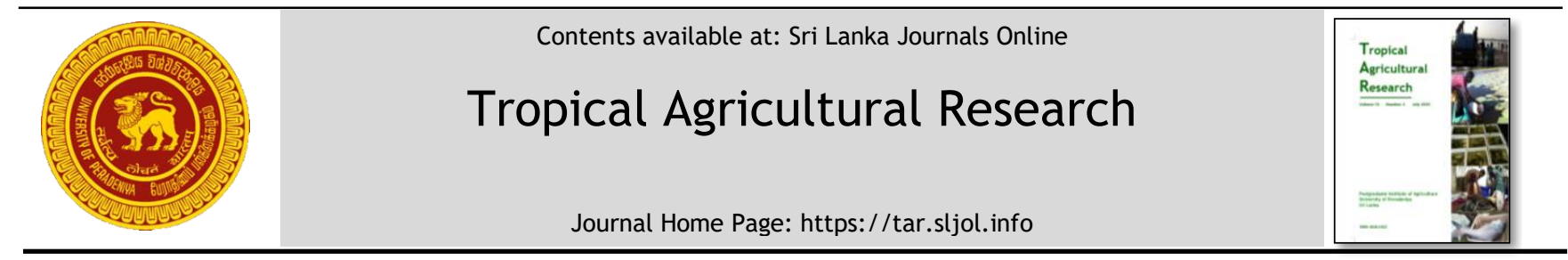

\title{
Small Pelagic Fish Value Chain and Its Contribution to Local Food Security: A Case Study in Gandara Fishing Village in Southern Coast of Sri Lanka
}

\author{
K.K.L. Hasini ${ }^{1,2^{*}}$, W.N. De Silva ${ }^{1}$ and J. Santos ${ }^{2}$ \\ ${ }^{1}$ Faculty of Agriculture, University of Ruhuna, Mapalana, Kamburupitiya, Sri Lanka. \\ ${ }^{2}$ Faculty of Biosciences, Fisheries and Economics, University of Tromso, Norway.
}

\section{ARTICLE INFO}

Article history:

Received: 14 August 2019

Accepted: 11 November 2019

Revised version received: 19 June 2020

Available online: 01 July 2020

\section{Keywords: \\ Fish \\ Food security \\ Marketing \\ Pelagic \\ Value chain}

\section{Citation:}

Hasini, K.K.L., De Silva, W.N. and Santos J. (2020). Small Pelagic Fish Value Chain and Its Contribution to Local Food Security: A Case Study in Gandara Fishing Village in Southern Coast of Sri Lanka. Tropical Agricultural Research, 31(3): 6071.

DOI: http://doi.org/10.4038/tar.v31i3.8397

Hasini, K.K.L. ID

https://orcid.org/0000-0001-9188-323X

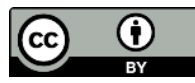

\section{ABSTRACT}

The small pelagic fishery has a critical importance both in terms of economic and food security concerns for coastal communities around the world. This study aimed at investigating the domestic fish value chain along with key economic agents, their roles and functions and to assess the contribution of the value chain to the local food security. In-depth interviews were conducted with at least five agents at each node of the value chain, and they were selected through stratified purposive and snowball sampling. Six different marketing channels were identified from fishers to consumers. Fishers are the primary producers. Local wholesalers played a conclusive role as the major middlemen, commission agents and money lenders. Regional suppliers transported fish from landing sites to the wholesalers of other regional markets. The retail market consisted of mobile fish vendors and local retailers. Ninety-eight percent of the commercial catch reached the consumer, with only $2 \%$ waste or by-usage. Seventy percent of that commercial catch directly moved to the local consumers along three marketing channels. The prominent channel was "Fisher-Retailer-Consumer" (37\%). This value chain had a significant contribution to local food security in terms of availability, accessibility, utilization and stability. The consumer price was affected by the number of intermediaries involved in the chain. Less number of intermediaries along the chain will improve the local food security while ensuring an affordable price for the consumers. Local consumers prefer fresh fish which hinders the desire of value creation in domestic value chains.

*Corresponding author : hasinikahandage@gamil.com 


\section{INTRODUCTION}

A well-functioning value chain always ensures the availability of an adequate amount of safe and nutritious food. Therefore, such a value chain significantly contributes to the food security of local vulnerable populations (Maestre et al., 2017). According to the definition of World Food Summit 1996, food security refers when all people, at all times, have physical and economic access to sufficient, safe and nutritious food that meets their dietary needs and food preferences for active and healthy life $(F A 0,1996)$. Food security is a multi-dimensional concept. The key dimensions of the food security concept are availability of food, access to food, utilization of food and stability of those three dimensions over time (FAO, 2002).

According to the report on Sri Lanka Food Security Atlas by World Food Programme (WFP) and Hector Kobbekaduwa Agrarian Research and Training Institute (HARTI) (2015), there are nearly 20 livelihood zones in Sri Lanka. Each livelihood zone of Sri Lanka is classified based on the level for food security (WFP and HARTI, 2015). Accordingly, Southern coastal area is named as LK03 Southern coastal tourism and fishing zone. Households in this coastal area mainly engage with fishing related livelihood activities (WFP and HARTI, 2015). As coastal fishing is highclimate sensitive livelihood approach, the income of fishing communities is threatened with climate hazards or extreme weather events (FAO and WFP, 2017). According to Sri Lankan food security and resilience level mapping, Southern coastal zone is considered as an occasional food insecure zone. It implies that this southern coastal area is subjected to occasional climate-related hazards, resulting in livelihood disruptions and eventually rising food insecurity (WFP and HARTI, 2015).

On the other hand, fish has a greater contribution to food security as a source of animal protein, essential fatty acids and a range of micronutrients (Belton and Thilsted, 2014). The small pelagic fish species such as Frigate Tuna (Alagoduwa), Bigeye scad (Bolloa), Herrings (Hurulla), Sardinella (Salaya) and Indian Scad (Linna) which adequately feed the local and regional markets at relatively cheap prices, have a significant contribution to local food security in Sri Lanka. The total annual marine fish production was $439,000 \mathrm{Mt}$ in 2018, which accounted for $85 \%$ of the total fish production of the country. Two hundred and forty-nine thousand Mt of coastal and lagoon fish production and the rest of offshore fish production $(190,000 \mathrm{Mt})$ were recorded during 2018 (Central Bank of Sri Lanka, 2018). More than $60 \%$ of the animal protein requirement of the people in Sri Lanka is provided through the fish intake (NARA, 2017). Therefore fishery has a tremendous opportunity to enhance the food and nutrition security among local communities as an income source of fishing communities and a readily available source of animal protein and other essential micronutrients (Bene et al., 2016).

It is generally believed that the current economic performance of the industry is far lower than the available fishery resources and potential in Sri Lanka. Therefore, extensive value chain analysis is essential to identify the current industry performances. Also, there are no significantly documented studies which analyse the collaborative impact of both value chain and food security concepts in Sri Lanka.

Therefore, this study was undertaken to investigate key economic agents, their roles and functions along the chain, to estimate the flows of fish through various marketing channels with the monetary and quantity based valuation and finally to assess the contribution of the small pelagic fish value chain on local food security.

\section{MATERIALS AND METHODS}

A value chain refers 'the full range of activities which are required to bring a product or service from conception, through the different phases of production which involving a combination of physical transformation and the input of various producer services, and then delivery to final consumers, and final disposal after use' (Kaplinsky and Morris, 2000). The value chain concept is used to evaluate the product or service flow of an industry considering its' monetary, quantitative or qualitative aspects (Webber and Labaste, 2009). Increasingly, studies on 
fisheries economics and management have been using value chain concept to evaluate the industry performances under a variety of objectives. Use of value chain concept within the context of food security can be observed in several studies (Bolwig et al., 2010; Belton and Thilsted, 2014; Youn et al., 2014; Bene et al., 2016; Maestre et al., 2017).

Gandara, an anchorage which is located in Gandara Fisheries Inspector Division of Matara district was purposively selected to carry out this study. It is the largest anchorage of Matara District both in terms of fish production and operating vessels. The landings of Gandara mainly consists with small pelagic species such as Frigate Tuna (Alagoduwa), Bigeye scad (Bolloa), Herrings (Hurulla), Sardinella (Salaya) and Indian Scad (Linna). This small pelagic fishery is dominated by single day OFRP (Outboard Fibre Reinforced Plastic) boats using mostly gill nets.

First, the strata or nodes of the value chain structure were identified through a preliminary study. Then, at least five agents at each node were selected through stratified purposive or snowball sampling. In total, the sample consisted of 48 value chain participants. All nodes of the chain were investigated with in-depth interviews which were guided by semi-structured questionnaires. Informal discussions and field observations were also used to collect primary data. This study was undertaken during MayAugust in 2018.

This study followed a mixed methodological approach which effectively combined both qualitative and quantitative data. Analysis of data was done by a few steps. First, the key economic agents, their roles and main functions were identified. A pilot survey which was conducted at the research site was utilized for that purpose. Then, the basic configuration of the chain was mapped. It showed the alignment of key economic agents along the chain. The product flow which implies the movement of fish from one node to another node of the chain was simply calculated in percentages (Malorgio et al.,
2012). Then, key marketing channels were analysed to explore economic disparities along each channel. The marketing margins, marketing cost and profit margins were simply calculated based on the average values of the sample. The difference between the buying price and selling price was imputed as the marketing margin or added value. The marketing profit was calculated by deducting marketing cost from marketing margin (Islam et al., 2016).

Furthermore, this value chain study was effectively integrated with the food security concept to assess the contribution of the pelagic value chain on local food security dynamics. In that purpose, the theoretical background behind the contribution of the fisheries sector on food security was identified through a narrative literature review. Accordingly, the potential impacts of the small pelagic fish value chain on food security dynamics were identified under four themes, and further elaborated into twelve subthemes. The key questions and data needed for identifying the fisheries' contribution for food security which was suggested by Bennett et al. (2018) and Gelli et al. (2015) was used as the framework of data collection. For instance, the questions on how much of fish available for home consumption, how much of fish leaks to the local market, what is the geographical coverage of value chain, the income generation through value chain activities were taken in to account at the data collection. Also, the perceptions of value chain actors regarding food security aspects were evaluated based on the Likert scale. Based on the results, a conceptual framework was developed by incorporating inherent qualitative characteristics of the small pelagic value chain with regards to four dynamics of food security.

\section{RESULTS AND DISCUSSION}

The small pelagic fish value chain was aligned across four key stages; production, wholesaling, retailing and consumption. The following Table 1 summarizes the key stages, actors and their roles along with their primary functions within the value chain. 
Table 1. Key stages, actors, their roles and functions within the value chain

\begin{tabular}{|c|c|c|c|}
\hline Key stage & Agents & Roles & Main functions performed \\
\hline \multirow[t]{4}{*}{ Production } & \multirow[t]{4}{*}{ Fishers } & \multirow[t]{4}{*}{-Harvesters } & $\begin{array}{l}\text {-Catching fish and bringing to the } \\
\text { landing sites }\end{array}$ \\
\hline & & & -Un-mesh /sometimes sorting \\
\hline & & & -Freezing/ chilling and storage \\
\hline & & & -Selling \\
\hline \multirow[t]{8}{*}{ Wholesaling } & \multirow{4}{*}{$\begin{array}{l}\text { Local } \\
\text { wholesalers } \\
\text { (in harbour) }\end{array}$} & \multirow{4}{*}{$\begin{array}{l}\text {-Intermediaries } \\
\text {-Boat owners } \\
\text {-commission agents } \\
\text {-Money lenders } \\
\end{array}$} & -Purchase fish from fishers and re- \\
\hline & & & sell \\
\hline & & & -Auction \\
\hline & & & -Sorting and grading \\
\hline & \multirow[t]{3}{*}{$\begin{array}{l}\text { Regional } \\
\text { suppliers }\end{array}$} & \multirow[t]{3}{*}{$\begin{array}{l}\text {-Distributors } \\
\text {-Transporters }\end{array}$} & $\begin{array}{l}\text {-Distribution of fish to regional } \\
\text { retailers or wholesalers }\end{array}$ \\
\hline & & & -Freezing or chilling \\
\hline & & & -Storage \\
\hline & Wholesalers & $\begin{array}{l}\text {-Sellers at central } \\
\text { regional markets }\end{array}$ & $\begin{array}{l}\text {-Selling fish to local retailers or } \\
\text { consumers }\end{array}$ \\
\hline \multirow[t]{2}{*}{ Retailing } & \multirow[t]{2}{*}{ Retailers } & $\begin{array}{l}\text {-Mobile fish vendors } \\
\text { (Cycle carriers) }\end{array}$ & \multirow[t]{2}{*}{$\begin{array}{l}\text {-Purchase fish from wholesalers and } \\
\text { re-sell to consumers. }\end{array}$} \\
\hline & & $\begin{array}{lr}\text {-Local sellers (at } \\
\text { roadsides } & \text { and } \\
\text { weekly fairs) } & \\
\end{array}$ & \\
\hline \multirow[t]{2}{*}{ Consumption } & \multirow[t]{2}{*}{ Consumers } & -Local consumers & \multirow[t]{2}{*}{ Preparation and consumption } \\
\hline & & $\begin{array}{l}\text {-Food catering } \\
\text { services ( Hotels, } \\
\text { restaurants) }\end{array}$ & \\
\hline
\end{tabular}

All the actors were responsible to facilitate the delivery of fish from harvesting to final consumers. The strategic positioning of each actor along the value chain was determined by their roles and functions. The role of local wholesaler was conclusive and more powerful within the fisheries value chain as they informally contract for the entire catch of fishermen through money lending. Therefore, credit diversification and establishment of pro-active fishers' sales organizations are important measures to empower the fishers.

There were some inherent features of this value chain. They were primarily harvesting driven value chains, therefore a less control over the quantity, quality or price of the fish along the value chains. The main objective of each actor was profit maximization rather than consumer satisfaction. Value chain actors tried to sell whatever they had to the respective buyers at the highest possible price. Also, there was no higher value addition along the chain rather than sorting, grading, chilling or transportation activities.

\section{Product flow}

Ninety-eight per cent of the catch entered the fish marketing channels from fishers' level while the remaining $2 \%$ accounted for wastage and non-commercial usage. The wastage occurred due to the poor on-board handling or overloading. The non-commercial catch implied home consumption and community sharing. The commercial catch (98\%) moved along six prominent marketing 
channels as follows. However, these channels were not mutually exclusive because multidirectional product flow from a single node of the value chain can be observed. The percentage quantity moving along each channel is mentioned within the parentheses.

Chanel 1: Fisher- Retailer- Consumer (37\%)

Chanel 2: Fisher- Local wholesaler- Consumer (3\%)

Chanel 3: Fisher- Local wholesaler- RetailerConsumer (30\%)

Chanel 4: Fisher- Local wholesaler- Regional supplier- Retailer- consumer (19\%)

Chanel 5: Fisher- Local wholesaler- Regional supplier- Wholesaler- consumer (2\%)

Chanel 6: Fisher- Local wholesaler- Regional Supplier- Wholesaler- Retailer- Consumer (7\%)

The channel 4, 5 and 6 appeared only when the fish was being transported far from the landing sites. A larger portion of the catch was passed through the local wholesalers (61\%).
It implied the irreplaceable and conclusive role of local wholesalers as the most powerful intermediaries in most of the channels. Marketing channels of the small pelagic fishery, generally aim to reach the coastal consumers in the region through very short marketing channels. Seventy percent of commercial catch moved to those local coastal communities through channels 1,2 and 3 . The highest percentage of the commercial catch (37\%) was directly purchased by local retailers and they sold directly to the final consumers. Local wholesalers sold nearly the same amount of fish to retailers and regional suppliers, i.e. $30 \%$ and $28 \%$ respectively. Also, $3 \%$ of fish of the local wholesalers were directly purchased by coastal consumers who came to the landing site to purchase a relatively larger amount $(2 \mathrm{~kg}-10 \mathrm{~kg})$ at the wholesale price. Regional suppliers distributed $19 \%$ of fish to the retailers while the remaining $9 \%$ was distributed to the wholesalers (Figure 1).

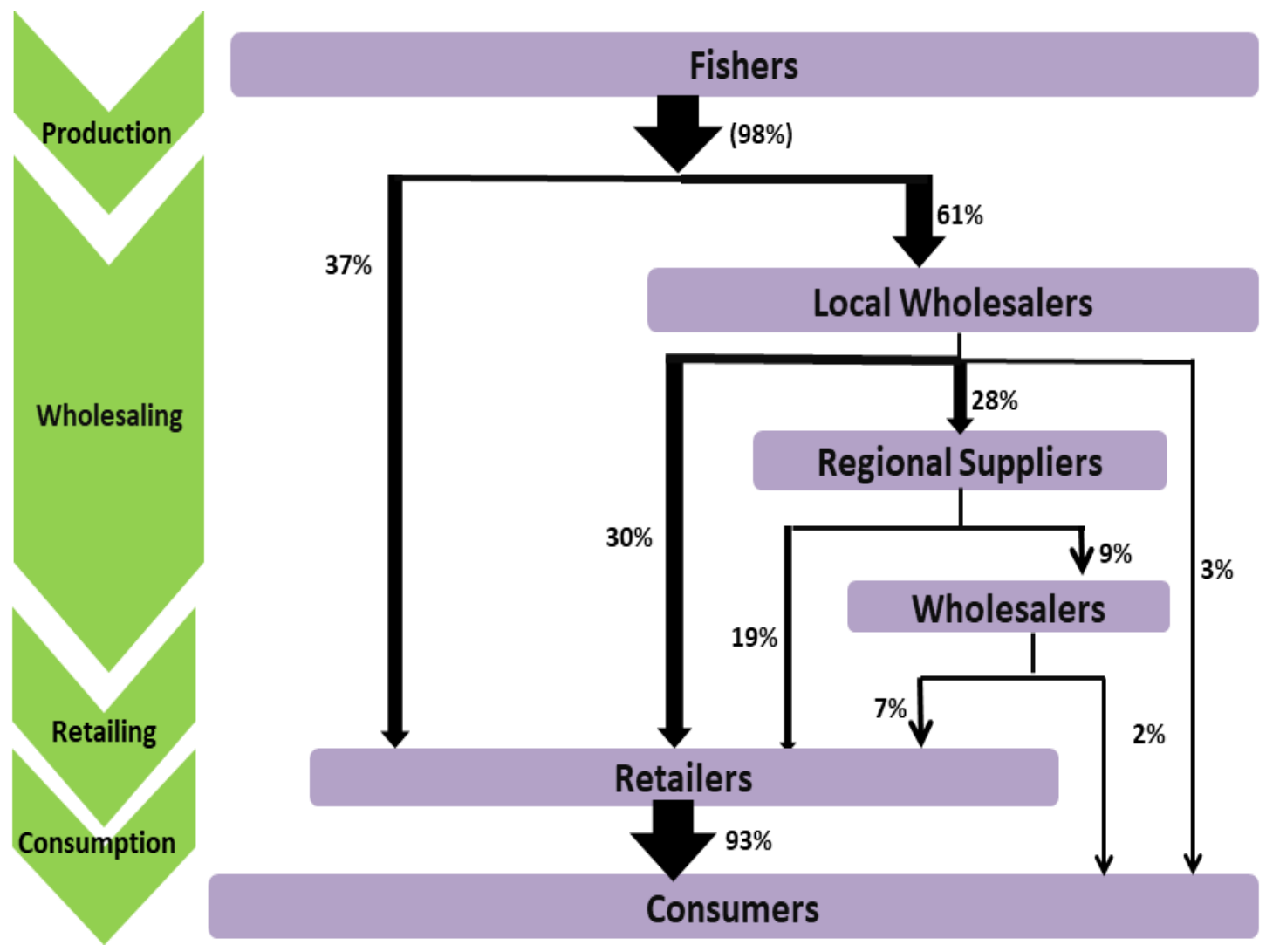

Figure 1. Value chain structure of small pelagic fish species in Southern Sri Lanka (Numerical values represents the weight-based flow of fish) 
The marketing cost represented the variable cost incurred by each actor in order to transfer a commodity from the previous agent to the next proceeding agent of the channel. The marketing cost mainly consisted of labour cost (including the opportunity cost) and operational costs such as expenditure for fuel and ice. Other cost items represented the commissions, repairing cost or port charges. A significant variation of the marketing cost incurred by each economic agent could be observed based on the nature of the marketing functions undertaken by them. As the primary producers, the fishers incurred the highest marketing cost (191 LKR/kg) compared to the other economic agents. This was due to the higher cost associated with fishing activities. Accordingly, fishers have the highest operational cost $(67 \mathrm{LKR} / \mathrm{kg})$ and the highest labour cost (117 LKR/kg). Also, the lowest cost was reported for wholesalers (3 LKR/kg).

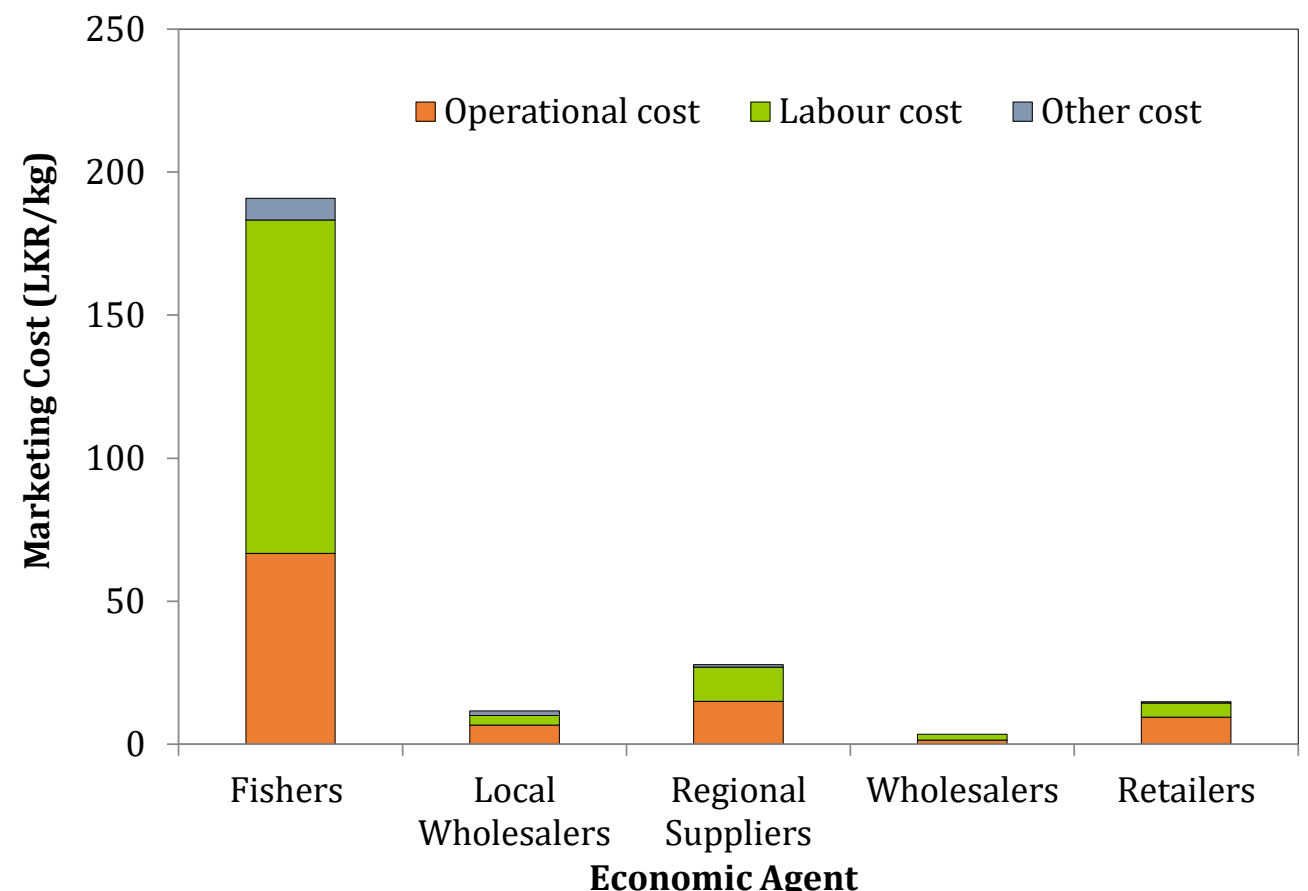

Figure 2. Composition of the marketing cost of each economic agent

The monetary components of the six marketing channels are summarized in the following Table 2. In general, when the length of the channel increases the price spread or marketing margin over the channel was increased. As a result, inflated prices for consumers could be observed for longer channels. For instance, a consumer of channel one was able to purchase fish for $300 \mathrm{LKR} / \mathrm{kg}$. However, a consumer of channel six had to pay $450 \mathrm{LKR} / \mathrm{kg}$. Hence, in the consumer perspective, channel 1 was the most favourable channel and channel 6 was the least favourable one. This implied the importance of short marketing channels with fewer intermediaries to ensure affordable consumer prices. However, the role of the intermediaries in some channels cannot be underestimated due to their marketing functions. In such cases, the market prices of fish should be regulated through a proper market pricing mechanism. A proper market information system will be important to develop marketdriven value chains.

Further, a proportionate increment of the associated marketing cost and profit could be observed with the length or the number of middlemen along the chains. The highest total marketing cost and the profit margin were reported for channel 6 . As a result of the lack of proper market price regulation mechanism, value chain actors always tend to ensure their profit margins while covering their cost by increasing the consumer prices. 
Table 2. Monetary valuation of each marketing channel

\begin{tabular}{cccccc}
\hline Channel No & $\begin{array}{l}\text { Fishers' } \\
\text { Price } \\
\text { (LKR per kg) }\end{array}$ & $\begin{array}{l}\text { Consumer } \\
\text { Price } \\
\text { (LKR per kg) }\end{array}$ & $\begin{array}{l}\text { Total } \\
\text { Marketing } \\
\text { Margin } \\
\text { (LKR per kg) }\end{array}$ & $\begin{array}{l}\text { Total } \\
\text { Marketing } \\
\text { Cost } \\
\text { (LKR per kg) }\end{array}$ & $\begin{array}{l}\text { Profit } \\
\text { Margin } \\
\text { (LKR per } \\
\text { kg) }\end{array}$ \\
\hline Channel 1 & 250 & 300 & 300 & 205.72 & 94.28 \\
Channel 2 & 250 & 300 & 300 & 202.51 & 97.49 \\
Channel 3 & 250 & 350 & 350 & 217.39 & 132.61 \\
Channel 4 & 250 & 410 & 410 & 245.19 & 164.81 \\
Channel 5 & 250 & 400 & 400 & 233.81 & 166.19 \\
Channel 6 & 250 & 450 & 450 & 248.69 & 201.31 \\
\hline
\end{tabular}

The following Figure 3 shows the percentage of marketing cost and percentage of the profit of each economic agent at different marketing channels. The highest marketing cost and profit margin were made by the fishers at every channel. However, the percentage of the profit of the fishers was always less than the percentage of the cost they incurred and generally, other actors received a higher profit margin comparing to the percentage of marketing costs they incurred. For example, fishers of channel 6 incurred $77 \%$ of the cost of the entire marketing channel. However, their gain was $30 \%$ while the remaining $70 \%$ of profit was shared among other actors. The intermediaries enjoyed a higher profit margin at far lower costs. Accordingly, there was a significant inequality and unfairness of gain distribution along the marketing channels.

$\square$ Fishers $\square$ Local Wholesalers $\square$ Regional Suppliers $\square$ Wholesalers $\square$ Retailers

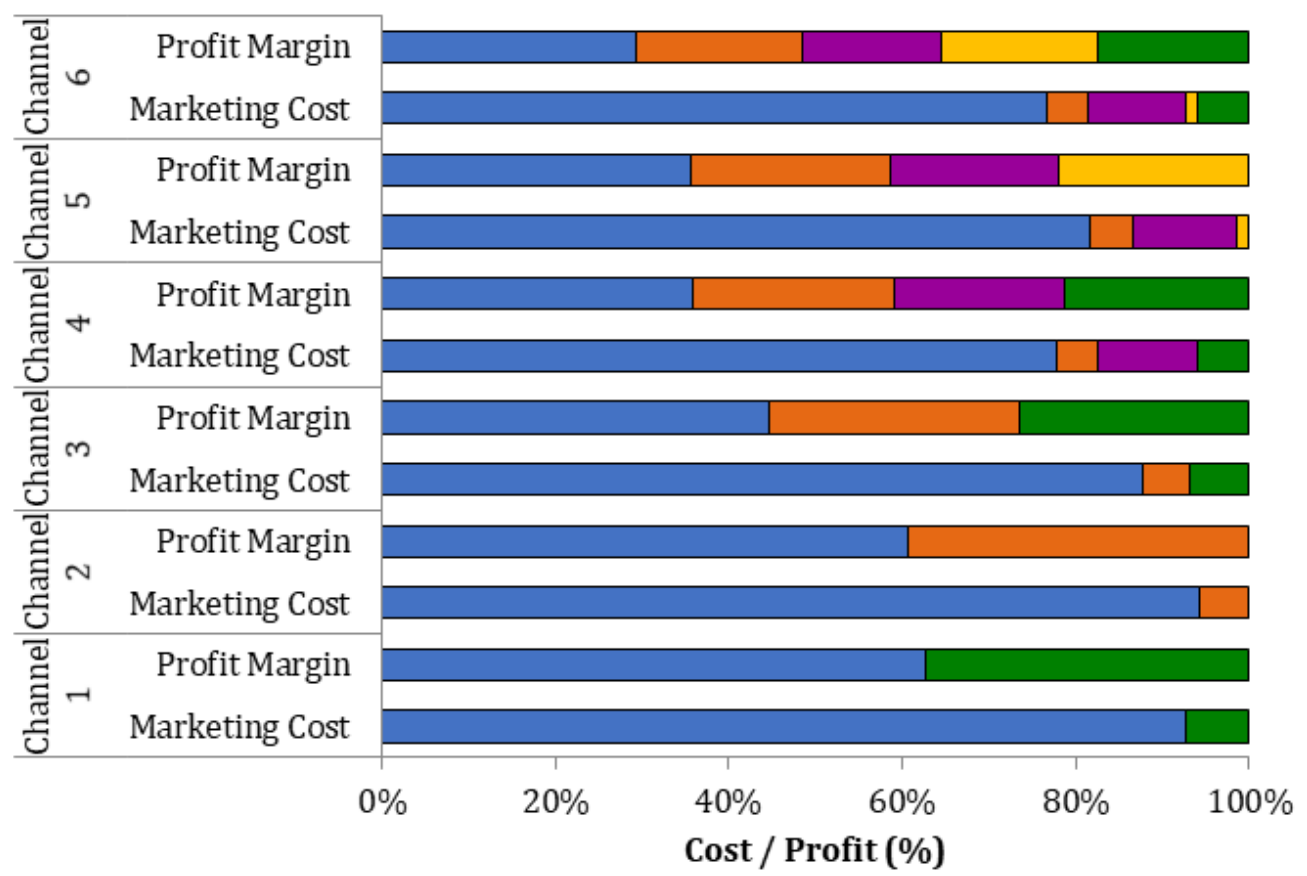

Figure 3. Distribution of cost (\%) and profit (\%) through each marketing channel 


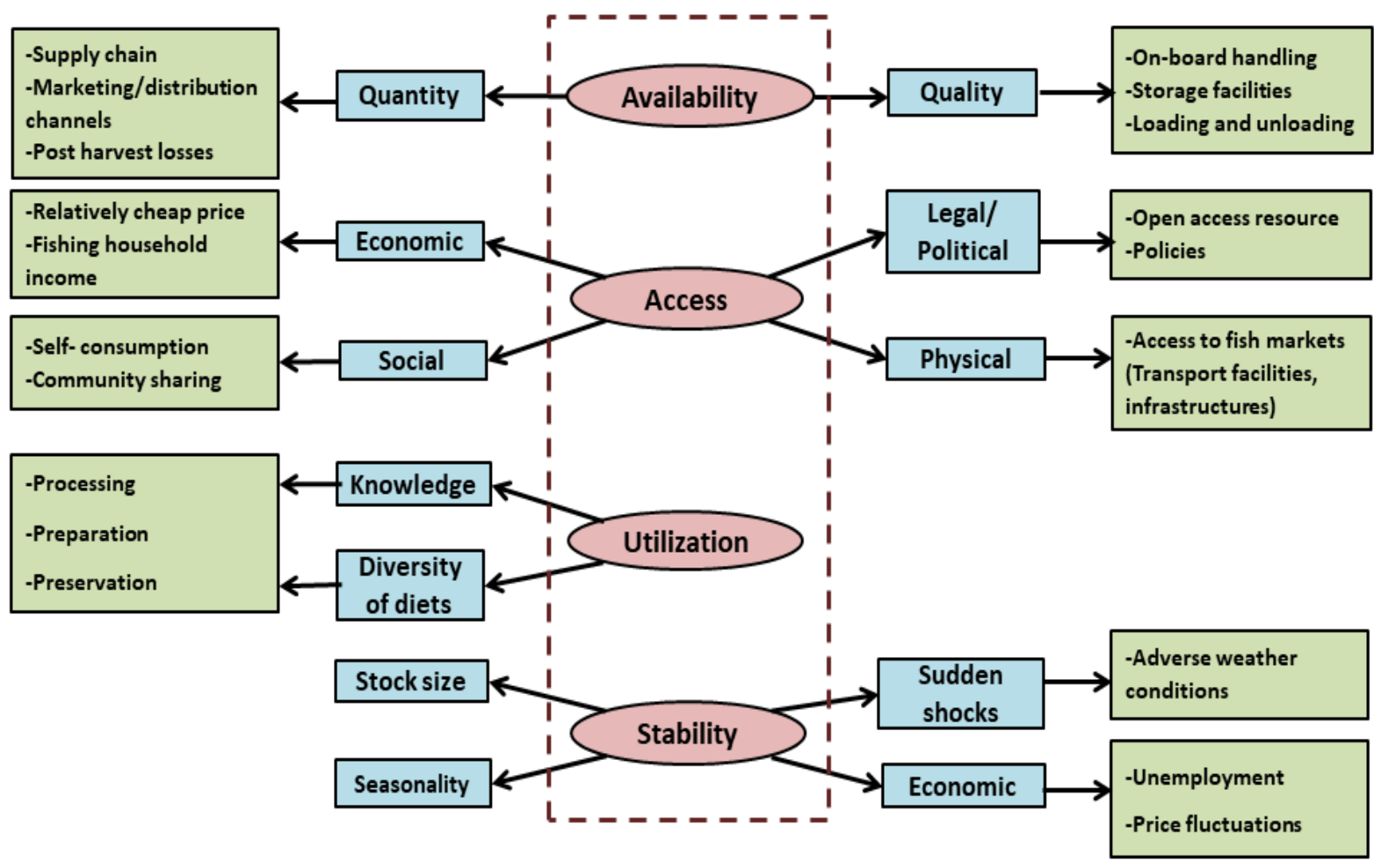

Figure 4. The contribution of small pelagic fishery for the local food security - A conceptual framework for analysing key food security dimensions

As Jayantha and Silva (2010) concluded Sri Lankan fishery value chains are dominated by few players. Number of intermediaries through the value chains is high and hence the cost of production is increasing without adding value to the chain (Jayantha and Silva, 2010).

The disparities of distribution of benefits among different chain actors were observed in many value chain studies including Cambodia and Vietnam. The highest profit was obtained by the wholesalers in Cambodia, and by the collectors in Vietnam (Sinh et al., 2014).

According to Phiri et al. (2013), the unfairness of the distribution of gains was observed in Chambo value chains in Malawi. An exploratory study on Australian farmed barramundi was conducted by Howieson et al. (2013). According to Howieson et al. (2013) the similar patterns of multiple marketing channels dominated by the wholesalers were reported.

\section{Contribution to the local food security}

The contribution of the small pelagic fishery to the food and nutrition security has two facets. Fish is highly nutritious, readily available, most frequently purchasing and the cheapest animal protein source in Sri Lanka. The main livelihood of coastal communities is fisheries which increase their purchasing power to access diversified, nutritious and balanced dietary intakes. The risk of food insecurity is an intrinsic nature of most of the vulnerable fishing populations, particularly in the small-scale fishery sector. The Figure 4 which was developed through the findings of the study, which critically elaborates the contribution of the small pelagic fish value chain to the local food security. The key features of the pelagic fish value chain are categorized under four dynamics as availability, access, utilization and stability.

The contribution of fisheries value chains on food security has examined by several studies. A comprehensive analysis 
undertaken by Belton and Thilsted, 2014 in ten countries, also concluded that capture fisheries provide diverse, nutritional and culturally preferred fish species which are easily accessed by the poor households. Fisheries play major roles in ensuring the global food security particularly providing animal protein and essential micro nutrients for local communities (Bolwig et al., 2010; Youn et al., 2014). A conceptual framework developed by Maestre et al. (2017) also suggested effective integration of agro-food value chains with the primary focus on food security to increase the intakes of nutrientdense food by vulnerable groups.

\section{Availability}

Fishery is an important food production system which has direct contribution to the food security(Bene et al., 2016). Available quantity of fish and the quality of those fish in the domestic market were the dominant features considered to evaluate the contribution of the supply chain or value chain to the local food security. According to this study, almost $70 \%$ of the small pelagic catch of the value chains was readily available for the local coastal consumers. The supply chains which were focused on the coastal consumers were very short with one or two intermediaries in between fishers and consumers. Therefore, local consumers can easily access to very fresh and safe fish through those short marketing channels. Also, the frequency of purchasing pelagic fish species also is an important indicator for assessing the market availability of fish. As this study found, more than $65 \%$ of responded coastal consumers purchased small pelagic species at least once a week, which suggested that the market availability of small pelagic species was not a critical issue particularly for coastal consumers.

The quality of the fish was basically dependent on the handling of fish along the supply chain. Due to relatively short sailing distance and duration, ice was not available in the boats. However, after landing, fishermen manage to store their catch in iceboxes, if it remained several hours to begin the morning fish market. Sometimes, overloading of fish in the boat caused to degrade the quality of fish and ultimately towards significant wastage. This study found that the loss of fish was around 2\% due to poor on-board handling. Poor storage facilities and unloading practices along the chain were examined as critical factors for the quality of fish that reached the final consumers. Poor handling of fish, particularly in the long marketing channels was a critical issue for safety and quality concerns. However, 78\% of coastal consumers who were interviewed were satisfied or highly satisfied with the quality and the freshness of the pelagic fish species that they purchased. As Kumolu-Johnson and Ndimele (2011) and Akande and DieiOuadi (2010) suggested the both quantitative loss and the qualitative loss throughout the value chain is a critical issue.

\section{Accessibility}

The accessibility of consumers to fish can be characterized in four perspectives as economic, social, legal/political and physical. In an economic perspective, these pelagic fish species were relatively cheaper than the other species. The average retail price of small pelagic species ranged from LKR 360 to LKR 400 per kilogram. These prices were far lower than the average price of tuna and other high valued species. Therefore, low-income households are able to purchase this fish easily than other sources of animal protein.

However, the strategies which allow for reducing the number of intermediaries may be facilitating the vertical integration along the chain will improve the local food security while ensuring affordable price for local consumers. Small-scale fishing households are normally considered as a vulnerable population with quite high income fluctuations. As the study revealed, fishers experience at least 5 days per month with zero income. Also, they mentioned that the market price of fish highly fluctuated based on the total landings at the harbour on a particular day. These fluctuations ultimately effect the income level and access to other 
food expenditures of value chain actors and their families. Value addition will be important to the handle seasonal fluctuations of the fishery industry. It is important to encourage the value addition through the knowledge raising and capacity building of the value chain actors.

On the other hand, the income generated from fishing related activities improves the purchasing power of the fishing households. It allows them to access for a balanced and nutritious dietary intake to maintain a healthy and active life. The most significant contribution was made by the selfconsumption and sharing among households of the fishing community. More than $80 \%$ of value chain actors reported of keeping 3-5\% of the daily catch for their own consumption and sharing with neighbours.

\section{Utilization}

The coastal community had a significant knowledge of preparing, processing and preserving of fish. Their traditional knowledge and cultural preferences on the preparation of diversified fish dishes and preservative techniques such as dry fish making, salting can be considered as very important factors to ensure local food security.

As this study found, the knowledge of coastal consumers on preparation and perseveration such as making dried fish or jaadi was higher. In addition, fish has given an important contribution to the diversity of diets of these coastal communities because it allowed poor households to enjoy a wide range of fish other than the monotonous starchy diets.

\section{Stability}

The food security is ensured when a household has access to the food at any time. When the small pelagic fishery is concerned, it is affected by the bimodal seasonality which occurred due to the monsoonal patterns of Sri Lanka. Adverse weather conditions effect fishing activities too. Most of the fishers stated that their harvest was decreasing over time which is a sign of overexploitation of fish stock. Furthermore, the economically vulnerable fishing households have experienced food insecurity due to the inability of engaging in fishing activities under the adverse weather conditions.

\section{CONCLUSION}

The small pelagic fishery comprised of six prominent marketing channels. Seventy percent of the commercial catch moved to the local coastal communities through the short marketing channels. Therefore, small pelagic fish species were readily available for the local coastal consumers at a reasonable price range. Local consumers could easily access very fresh and safe fish. Poor storage facilities and unloading practices along the chain were the critical issues to ensure the quality and safety of fish. On the other hand, the food security of vulnerable fishing households was always threatened by the fluctuations of the harvest and income.

The highest marketing cost was incurred by the fishers $(191 \mathrm{LKR} / \mathrm{kg})$ at every marketing channel while the lowest cost was incurred by wholesalers ( $3 \mathrm{LKR} / \mathrm{kg}$ ). The fisher to retailer price spread was comparatively high across the longer market channels. The highest total marketing cost and the profit margin were reported for channel 6 which implied the movement of fish along with Fisher- Local wholesaler- Regional supplierWholesaler- Retailer to Consumer. These domestic value chains were profitable, even though the distribution of gain was comparatively unfair. Fair distribution of retail prices should be ensured within the value chains.

Each actor of the value chain played a specific role which was required to transfer fish from harvesting to the final consumption. Fishers often get loans from local wholesalers due to lack of a formalized credit supply. It adversely influenced the bargaining power and the independent decision making. 


\section{REFERENCES}

Akande, G. and Diei-Ouadi, Y. (2010). Postharvest losses in small-scale fisheries: Case studies in five sub-Saharan African countries. FAO Fisheries and aquaculture Technical Paper 550, Food and Agriculture Organization.

Belton, B. and Thilsted, S.H. (2014). Fisheries in transition: Food and nutrition security implications for the global South. Global Food Security. 3(1), 5966.

https://doi.org/10.1016/j.gfs.2013.1 0.001

Bene, C., Arthur, R., Norbury, H. and Allison, E.H., Beveridge, M.C.M., Bush, S.R., Campling, L., Little, D.C., Leschen, W., Squires, D., Thilsted, S.H., Troell, M. and Williams, M. (2016). Contribution of Fisheries and Aquaculture to Food Security and Poverty Reduction: Assessing the Current Evidence. World Development, 79, 177-196. https://doi.org/10.1016/j.worlddev.2 015.11.007

Bennett, A., Patil, P., Kristin, K., Rader, D., Virdin, J. and Basurto, X. (2018). Contribution of Fisheries to Food and Nutrition Security: Current Knowledge, Policy, and Research. NI Report 18-02. Durham, NC: Duke University, http:// nicholasinstitute.duke.edu/publicatio n.

Bolwig, S., Ponte, S., Du Toit, A., Riisgaard, L. and Halberg, N. (2010). Integrating Poverty and Environmental Concerns into Value-Chain Analysis: A Conceptual Framework. Development Policy Review. 28(2), 173-194.

Central Bank of Sri Lanka (2019). Annual report 2018, Sri Lanka. Available at https://www.cbsl.gov.lk/en/publicati ons/economic-and-financialreports/annual-reports
FAO (Food and Agriculture Organization of the United Nations) (1996). Rome Declaration on Food Security and World Food Summit Plan of Action. Available at http://www.fao.org/3/w3613e/w36 $13 \mathrm{e} 00 . \mathrm{htm}$

FAO (Food and Agriculture Organization of the United Nations) (2002). Measurement and Assessment of Food Deprivation and Under-nutrition. Proceedings of the International Scientific Symposium, Rome, 26-28 June 2002. Rome: FAO. Available at http://www.fao.org/3/a-y4250e.pdf

FAO (Food and Agriculture Organization of the United Nations) and WFP (World Food Programme). (2017). Special Report FAO/WFP Crop and Food Security Assessment Mission to Sri Lanka. Available at: http://www.fao.org/3/a-i7450e.pdf

Gelli, A., Hawkes, C., Donovan, J., Harris, J., Allen, S., Brauw, A., Henson, S., Johnson, N., Garrett, J. and Ryckembusch, D. (2015). Value Chains and Nutrition: A Framework to Support the Identification, Design, and Evaluation of Interventions. IFPRI Discussion Paper 01413. Washington, DC: IFPRI (International Food Policy Research Institute)

Howieson, J., Hastings, K. and Lawley, M. (2013). Creating Value in the Supply Chain for Australian Farmed Barramundi: Whole of Chain Perspective. Journal of International Food \& Agribusiness Marketing, 25 (4), 287-297, DOI: 10.1080/ 08974438.2013.728989.

Islam, M., Haque, M., Rabbani, M. and Sharmin, S. (2016). Marketing of shrimp in Bangladesh-A value chain analysis. Journal of the Bangladesh Agricultural University. 12(2), 359-368. https://www.banglajol.info/index.ph $\mathrm{p} / \mathrm{JBAU} /$ article/view/28696 
Jayantha, S.P.M. and Silva, D.A.M. De. (2010). Supply Chain Management in the Aquaculture Industry: The Case of Food Fish Aquaculture in Sri Lanka. Sabaramuwa University Journal. 9(1), 147-169.

Kaplinsky, R. and Morris, M. (2000). A Handbook for Value Chain Research. International Development Research Center (IDRC), Ottawa, Canada. http://www.ids.ac.uk/ids/global/pdf s/VchNov01.pdfs/vchnov01.pdf

Kumolu-Johnson, C.A., and Ndimele, P.E. (2011). A review of postharvest losses in artisanal fisheries in some African countries. Journal of Fisheries and Aquatic Science. 6(4), 365-378.

Maestre, M., Poole, N. and Henson, S. (2017). Assessing food value chain pathways, linkages and impacts for better nutrition of vulnerable groups. Food Policy. 68, 31-39. https://doi.org/10.1016/j.foodpol.20 16.12.007

Malorgio, G., Camanzi, L. and Grazia, C. (2012). Supply chain relationships and quality certification schemes: a case study in fisheries. Politica Agricola Internazionale. 1, 63-80.

NARA (National Aquatic Resources Research and Development Agency) (2018). Sri Lanka Fisheries Yearbook 2017. Crow Island, Colombo, Sri Lanka: NARA.

Phiri, L.Y., Dzanja, J., Kakota, T. and Hara, M. (2013). Value Chain Analysis of Lake
Malawi Fish: A Case Study of Oreochromis spp ( Chambo ). International Journal of Business and Social Science. 4(2), 170-181.

Sinh, L.X., Navy, H. and Pomeroy, R.S. (2014). Value Chain of Snakehead Fish in the Lower Mekong Basin of Cambodia and Vietnam. Aquaculture Economics and Management, 18(1), pp. 76-96. doi: $10.1080 / 13657305.2014 .855956$.

Webber, C.M. and Labaste, P. (2009). Building competitiveness in Africa's agriculture: A guide to value chain concepts and applications. Agriculture and Rural Development. Washington, D.C.: World Bank. Available at: http://siteresources.worldbank.org/I NTARD/Resources/Building_Competi tiveness_in_Afric a_Ag.pdf

WFP (World Food Programme) and HARTI (Hector Kobbekaduwa Agrarian Research and Training Institute). (2015). Sri Lanka Food Security Atlas. Livelihoods, Food Security and Resilience. Available at: https://documents.wfp.org/stellent/g roups/public/documents/ena/wfp28 0069.pdf

Youn, S., Taylor, W.W., Lynch, A.J., Cowx, I.G., Beard, T.D., Bartley, D. and Wu, F. (2014). Inland capture fishery contributions to global food security and threats to their future. Global Food Security. 3(3-4), 142-148. https://doi.org/10.1016/j.gfs.2014.0 9.005 . 